\author{
Anna Nowak \\ University of Life Sciences in Lublin \\ e-mail: anna.nowak@up.lublin.pl \\ ORCID: 0000-0003-1741-8692
}

\title{
THE COMPETITIVE POSITION \\ OF FARMS ACCORDING TO CLASS \\ OF ECONOMIC SIZE
}

\section{KONKURENCYJNOŚĆ WYNIKOWA \\ GOSPODARSTW ROLNYCH W ZALEŻNOŚCI OD ICH WIELKOŚCI EKONOMICZNEJ}

DOI: $10.15611 / \mathrm{pn} .2020 .3 .05$

JEL Classification: D24, Q18, Q12

\begin{abstract}
Summary: This paper aimed at evaluating the competitive position of farms in Poland according to class of economic size. The study was carried out based on data from the European system for collecting accounting data on farms, i.e. EU FADN, for 2015-2017. The analysis made use of work profitability ratios and partial productivity indicators referring to production factors. The studies revealed a relationship between the economic power of farms and the efficient utilisation of production factors. Economically stronger farms had a competitive advantage as regards the productivity of land, labour and capital, as well as work profitability. The conclusion is that continuing structural transformations in agriculture to optimise the structure of farms is justified. It was also demonstrated that Polish farms in respective classes of economic size were less competitive than their equivalents in the European Union.
\end{abstract}

Keywords: farms, competitive position, economic size, productivity.

Streszczenie: Celem opracowania była ocena poziomu konkurencyjności wynikowej gospodarstw rolnych w Polsce według klas wielkości ekonomicznej. Badania zrealizowano na podstawie danych europejskiego systemu zbierania danych rachunkowych z gospodarstw rolnych FADN EU z lat 2015-2017. Do analizy wykorzystano wskaźniki dochodowości pracy oraz cząstkowe wskaźniki produktywności czynników produkcji. Badania wykazały, że istnieje zależność pomiędzy siłą ekonomiczną gospodarstw i efektywnością wykorzystania czynników produkcji. Gospodarstwa silniejsze ekonomicznie osiagały przewagi konkurencyjne w zakresie produktywności ziemi, pracy i kapitału, a także dochodowości pracy. Wykazano również, że polskie gospodarstwa rolne poszczególnych klas wielkości ekonomicznej osiagały niską pozycję konkurencyjną względem tych samych klas w Unii Europejskiej.

Słowa kluczowe: gospodarstwa rolne, konkurencyjność wynikowa, wielkość ekonomiczna, produktywność. 


\section{Introduction}

Competitiveness generally means the capacity to gain an advantage over other entities, and the capacity to develop and, as a consequence, derive benefits (Nasalski, 2018, p. 120; Sipa, 2007, p. 301). Farms form a specific group of entities and their competitiveness is one of the most current issues in the areas of economics, politics and in scientific research. Nevertheless, no generally accepted comprehensive framework exists to evaluate competitiveness (Bachev, 2017, p. 1029). This is due to the fact that the notion of competitiveness is rooted in different economic theories. In addition, this is a complex issue taking multiple features of enterprises into account. In current economic conditions, the market competitiveness of an enterprise is perceived as an effect of the synergy between the multiple internal factors inherent in an enterprise and the external mechanisms and conditions in the business environment (Chrobocińska, 2014, pp. 137-138; Bachev, 2017, p. 1029). Thus, the competitive position of an enterprise is defined as a multi-dimensional category determined by a set of factors, however competitive advantage is a reflection of the enterprise's competitive position.

Due to its complexity and dependency on multiple conditions, both exogenous and endogenous, competitiveness must be evaluated according to many different criteria. The European Commission believes that productivity is the most reliable indicator of long-term competitiveness (European Commission, 2009, p. 7). Poczta and Siemiński (2010, p. 25) also emphasize that economic efficiency is of central significance for evaluating competitiveness in the microeconomic aspect. In turn, Latruffe (2010, pp. 7-30) classifies measures of agricultural competitiveness into those related to strategic management (e.g. production costs, profitability, productivity) and competitiveness ratios related to trade. The perception of competitiveness is often diversified into competitive advantage and competitive position (Gorynia, 2000, p. 89). The first refers to the capacity of enterprises to undertake measures underlying efficient competition, whilst the competitive position refers to the outcomes of competition (e.g. financial results, productivity) (Grzebyk and Kryński, 2011, pp. 112-113). This study is based on such an approach limited to the evaluation of the competitiveness of farms in the aspect of their results.

Farms in Poland differ to a large extent both in terms of directions of production and their production potential. According to data compiled by the Central Statistical Office (Główny Urząd Statystyczny [GUS]. 2017, p. 61), in 2016 Poland had 1410.7 thousand active farms, where farms with an area of up to 5 ha accounted for $54 \%$. In addition, the above-mentioned data indicates that the average area of an individual farm with more than a 1 ha share of agricultural land was only 10.3 ha. Farms also vary in terms of their economic potential. In 2016 , the economic size of nearly $65 \%$ of farms was up to 8 thousand euros, and only $2.4 \%$ were included in the economic size classes of 100 thousand euros and larger. This differentiation impedes analyses and generalizations on a whole sample of farms (Nosecka, Pawlak, and Poczta, 2011, 
p. 18). Thus, identifying more uniform groups of farms is justified. Bachev (2017, p. 1029) emphasizes that the competitiveness of farms is usually evaluated according to relative categories in comparison with other similar farms. This similarity may be based on economic size, i.e. total standard output (SO) from all agricultural activities practised by the respective farm and denominated in euros. This is a measure of the production capacity of a farm as well as its competitive potential (Orłowska, 2015, p. 190). This study aims at evaluating the competitive position of farms in Poland according to their class of economic size following the typology adopted by FADN (Farm Accountancy Data Network).

\section{Methods}

The studies were carried out based on data from the European system for collecting accounting data on farms, i.e. EU FADN. FADN's field of observation covers commodity farms. The use of unified databases offers the possibility of making expert assessments of more uniform groups of farms and comparisons between respective farms, between countries and regions (Grochowska and Mańko, 2014, p. 26). The time range of the study is 2015-2017. In order to mitigate the impact of random factors, the mean values from the study period were analysed.

The study covered Polish farms grouped into six classes according to their economic size. The ES6 classification identifies six classes of economic size of farms depending on their total standard output: class 1 - very small (2-8 thousand euros), class 2 - small (8-25 thousand euros), class 3 - rather small (25-50 thousand euros), class 4 - rather large (50-100 thousand euros), class 5 - large (100-500 thousand euros), class 6 - very large ( $\geq 500$ thousand euros) (Floriańczyk, Osuch, and Płonka, 2018 , p. 10). The results were compared against the mean results across the entire population of farms in the European Union (EU-28), also in six classes of economic size.

Farms in respective classes of economic size were analysed using selected indicators describing competitiveness in the aspect of competitive position. The indicators and the method of their calculation are presented in Table 1.

Table 1. Indicators for evaluating the competitive position of farms

\begin{tabular}{|c|c|c|c|}
\hline $\begin{array}{c}\text { Indicators } \\
\text { of competitive position }\end{array}$ & $\begin{array}{c}\text { Method } \\
\text { of calculation }\end{array}$ & $\begin{array}{l}\text { Symbols of variables } \\
\text { according to FADN }\end{array}$ & $\begin{array}{l}\text { Unit } \\
\text { of measure }\end{array}$ \\
\hline Work profitability & family farm income/AWU* & SE420/SE010 & EUR/AWU \\
\hline Land productivity & output/agricultural land (UAA) & SE131/SE025 & EUR/ha \\
\hline Labour productivity & output/AWU & SE131/SE010 & EUR/AWU \\
\hline Capital productivity & output/fixed assets & SE131/SE441 & EUR \\
\hline
\end{tabular}

*AWU (Annual Work Unit) - full-time equivalent.

Source: own elaboration. 
The analysis also covered selected features of farms from respective classes of economic size - the average economic size, labour input, average utilised agricultural area (UAA), gross investment per 1 ha UAA, gross value added per farm, number of workers per 100 ha UAA, technical resources and production intensity (total costs per 1 ha UAA). This allowed an assessment of the variations between classes of economic size.

\section{Results}

Table 2 presents selected features of farms according to the analysed classes of economic size in Poland and the average in the 28 member states of the EU (EU-28).

Table 2. Selected characteristic features of farms in Poland and in the EU according to class of economic size in 2015-2017

\begin{tabular}{|c|c|c|c|c|c|}
\hline $\begin{array}{c}\text { Classes of economic size } \\
\text { (EUR) }\end{array}$ & $\begin{array}{l}\text { SE005 } \\
\text { (thousand } \\
\text { EUR) }\end{array}$ & $\begin{array}{l}\text { SE010 } \\
\text { (AWU) }\end{array}$ & $\begin{array}{l}\text { SE025 } \\
\text { (ha) }\end{array}$ & $\begin{array}{l}\text { SE516/SE025 } \\
\text { (EUR/ha) }\end{array}$ & $\begin{array}{l}\text { SE410 } \\
\text { (EUR) }\end{array}$ \\
\hline \multicolumn{6}{|c|}{ Poland } \\
\hline (1) $2000-<8000$ & 6.8 & 1.2 & 7.5 & -2.8 & 4121.7 \\
\hline (2) $8000-<25000$ & 16.4 & 1.5 & 13.8 & 117.8 & 9640.0 \\
\hline (3) $25000-<50000$ & 36.4 & 1.9 & 23.6 & 206.3 & 21031.0 \\
\hline (4) $50000-<100000$ & 69.6 & 2.1 & 39.5 & 299.9 & 39678.3 \\
\hline (5) $100000-<500000$ & 180.2 & 3.3 & 85.2 & 322.0 & 92580.3 \\
\hline (6) $>=500000$ & 1092.6 & 19.4 & 548.6 & 146.9 & 452322.3 \\
\hline Total & 28.2 & 1.6 & 18.7 & 175.3 & 15443.7 \\
\hline \multicolumn{6}{|c|}{ EU-28 } \\
\hline (1) $2000-<8000$ & 5.2 & 1.0 & 4.7 & 87.5 & 3874.3 \\
\hline (2) $8000-<25000$ & 15.8 & 1.2 & 14.8 & 141.2 & 13612.0 \\
\hline (3) $25000-<50000$ & 36.8 & 1.4 & 30.0 & 174.5 & 27679.3 \\
\hline (4) $50000-<100000$ & 72.6 & 1.7 & 55.6 & 199.2 & 48866.7 \\
\hline (5) $100000-<500000$ & 217.9 & 2.5 & 104.7 & 324.4 & 121385.3 \\
\hline (6) $>=500000$ & 1152.4 & 8.9 & 292.7 & 470.5 & 515364.7 \\
\hline Total & 68.5 & 1.5 & 34.4 & 277.0 & 39218.3 \\
\hline
\end{tabular}

Key: SE005 - Economic size, SE010 - Total labour input, SE025 -Total Utilised Agricultural Area (UAA), SE516/SE025 - Gross Investment per 1 ha UAA, SE410 - Gross Farm Income.

Source: own elaboration based on EU FADN.

The presented data indicates that the average economic size of a farm in Poland is considerably smaller than the EU average. The respective classes of farms differed in their competitive potential. The potential is the sum of all the resources of the farm (Kagan, 2015, p. 14). In terms of improvement in the competitiveness of farms, the correct relationships between resources are particularly significant (Nosecka et al., 
2011, p. 44). The analysis covered the average utilised agricultural area of farms, where area is a conventional measure of a farm's size, however it remains the underlying criterion of the farm's economic power. The farm's utilised agricultural area determines the fundamental relationship between production and economy, which as a result is reflected by the farm's income (Marcysiak and Marcysiak, 2015, p. 168). The average UAA of a farm in Poland in 2015-2017 was 18.7 ha, ranging from 7.5 ha in class 1 to 548.6 ha in class 6 . In the EU-28, the average resources of land across the entire population of farms were nearly double that of Poland. Labour resources, both in Poland and in the EU-28, increased in higher economic size classes. A similar trend can be observed for gross value added, however in each of the analysed classes the average value in Poland was lower than in the EU-28. In addition, the respective classes of farms differed in their gross investment per 1 ha UAA. The average value of this indicator in Poland was 175.3 EUR per 1 ha, whereas it was $58 \%$ higher in the EU-28.

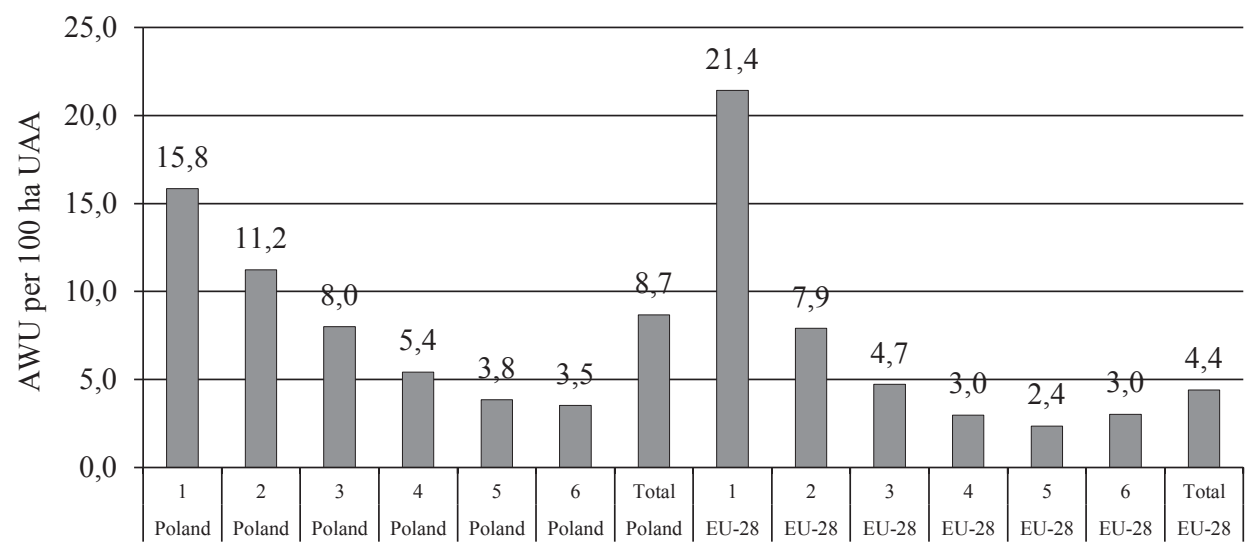

Economic size classes

Fig. 1. Number of workers per 100 ha of utilised agricultural area (UAA) on farms in Poland and in the European Union according to class of economic size in 2015-2017 (AWU/100 ha)

Source: own elaboration based on EU FADN.

The data presented in Figure 1 indicates that farms in respective economic size classes differed in labour input per 100 ha UAA. In Poland, this input decreased along with the increase in economic power. It is worth noting that the average number of annual work units (AWU) per 100 ha UAA was twice lower in Poland than in the European Union.

Analysing the capital resources of farms, the technical resources ratio was calculated as the relation between the value of fixed assets and the number of annual work units (SE441/SE010). It was found that the value of this indicator increased in 


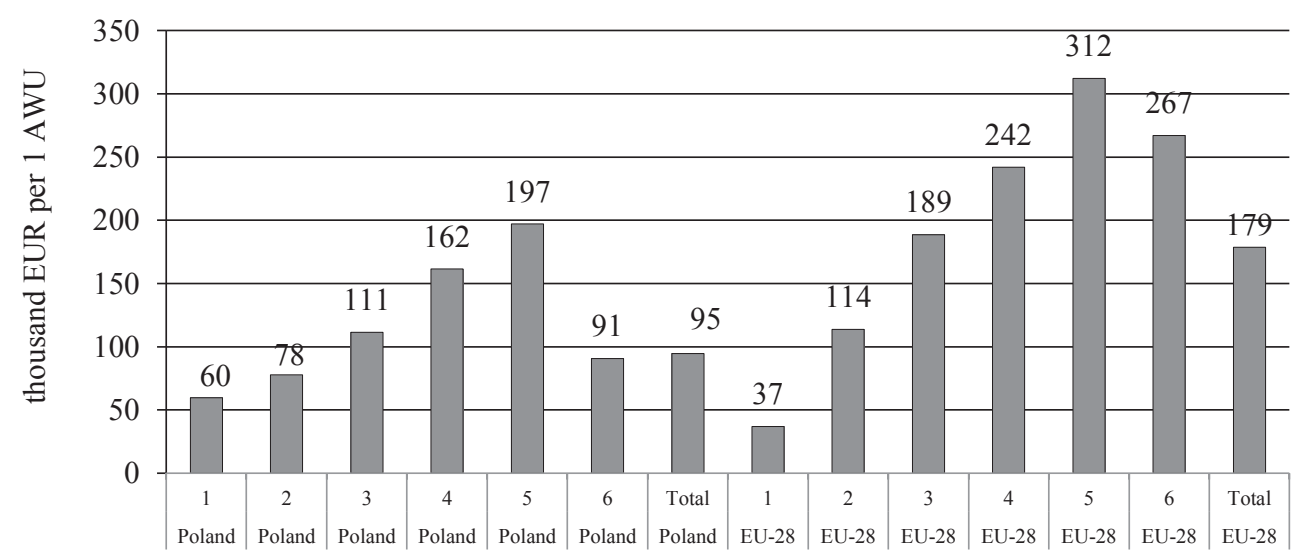

economic size classes

Fig. 2. Technical resources on farms in Poland and in the European Union according to class of economic size in 2015-2017 (thousand EUR per 1 AWU)

Source: own elaboration based on EU FADN.

higher classes of economic size, both in Poland and on average in the EU. The level of technical resources was lower only on the economically strongest farms. At the same time, it should be noted that in the years covered by the study, the level of technical resources in Poland was considerably lower in Poland than on average in the EU. The value of the indicator in Poland was on average twice lower than in the EU-28 (Figure 2).

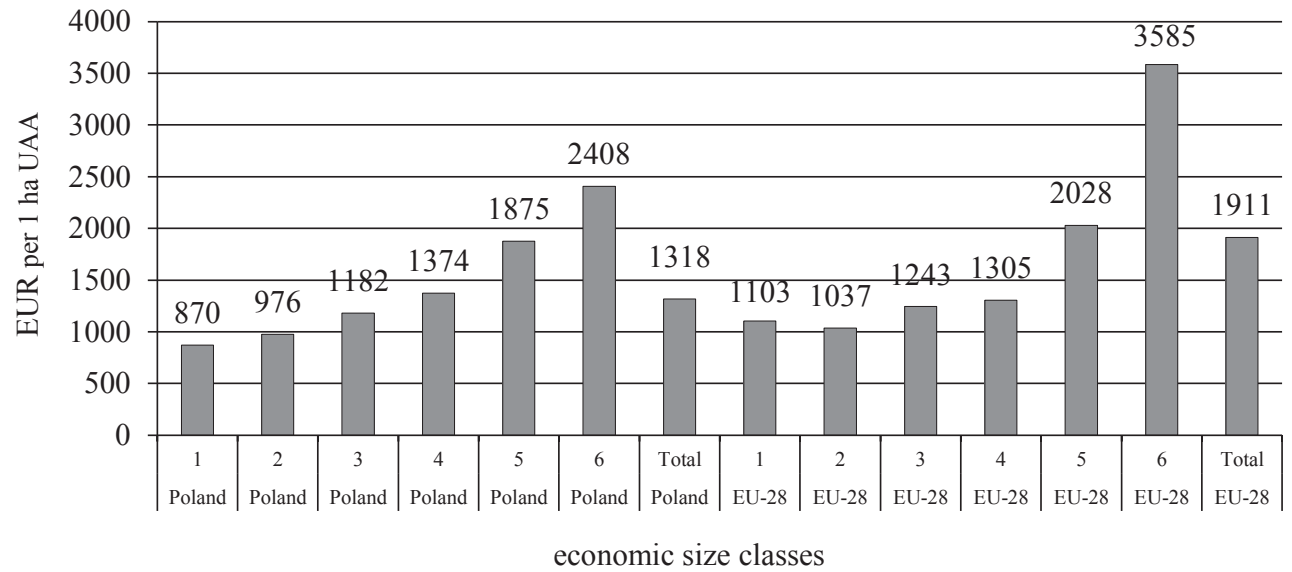

Fig. 3. Total costs per 1 ha of utilised agricultural area for farms in Poland and in the European Union according to class of economic size (EUR/ha)

Source: own elaboration based on EU FADN. 
The intensity of production in respective economic size classes was also evaluated (SE270/SE025). Figure 3 indicates that total costs per 1 ha UAA increase along with the increase in the farms' economic power. However, the mean value of this indicator for Poland was nearly $45 \%$ lower than on average in the EU.

Table 3. Work profitability of farms in Poland and in the EU according to class of economic size in 2015-2017

\begin{tabular}{|l|c|c|}
\hline \multirow{2}{*}{ Economic size classes (EUR) } & Work profitability (EUR/AWU) \\
\cline { 2 - 3 } & Poland & EU-28 \\
\hline (1) $2000-<8000$ & 1459.4 & 2292.4 \\
\hline$(2) 8000-<25000$ & 3300.3 & 7510.1 \\
\hline$(3) 25000-<50000$ & 6778.5 & 11552.9 \\
\hline$(4) 50000-<100000$ & 12032.4 & 16439.2 \\
\hline$(5) 100000-<500000$ & 17146.1 & 22384.1 \\
\hline (6) $>=500000$ & 5742.1 & 20131.6 \\
\hline Total & 5173.0 & 12362.4 \\
\hline
\end{tabular}

Source: own elaboration based on EU FADN.

The economic objective of agricultural activity is earning the expected income (Orłowska, 2019, p. 218). Thus, competitive advantages were determined based on work profitability (Table 3 ). The analysis of profitability of a farm gives an opportunity of assessing the financial benefits from agricultural activity and from available production factors (Kagan, 2015, p. 23). The studies showed that in classes from 1 to 5 , work profitability increased in the higher classes. The level of that indicator was relatively low only for farms of the largest economic size. Gałecka formulated similar conclusions during her study $(2017$, p. 69). The explanation is that such farms to a larger extent relied on hired labour, hence the costs of labour decreased the farm's income. If the farm work is performed by the farmer himself, the cost of labour is not deducted from income. The average cost of hired labour in 2015-2017 per 1 ha UAA in class 6 farms amounted to 390.5 EUR/ha, while the average cost for the whole sample of farms was $77 \mathrm{EUR} / \mathrm{ha}$ (EU FADN, 2020). Farms from economic size class 1 and 2 were characterized by lower than average work profitability. Średzińska (2017, pp. 305-314) claims that their low competitive position in that respect is a result of, among others, the relationship between income and the value of assets. With reference to the work profitability of EU farms, it must be stated that Polish farms of any class were not very competitive. The average income per 1 AWU in Poland in 2015-2017 was 58.2\% lower than on average in the EU-28.

Productivity is defined as the capacity of production factors to create production output (Latruffe, 2010, p. 18). A particularly significant role is assigned to labour productivity which is connected with the optimum utilisation of the farm's resources. The analysis of this indicator leads to the conclusion that the larger the economic size 
Table 4. The productivity of production factors on farms in Poland and in the EU according to class of economic size in 2015-2017

\begin{tabular}{|l|c|c|c|}
\hline $\begin{array}{c}\text { Economic size classes } \\
\text { (EUR) }\end{array}$ & $\begin{array}{c}\text { Labour productivity } \\
\text { (EUR/AWU) }\end{array}$ & $\begin{array}{c}\text { Land productivity } \\
\text { (EUR/ha) }\end{array}$ & $\begin{array}{c}\text { Capital productivity } \\
\text { (EUR) }\end{array}$ \\
\hline \multicolumn{3}{|c|}{ Poland } \\
\hline (1) $2000-<8000$ & 5370.3 & 850.9 & 0.09 \\
\hline (2) $8000-<25000$ & 9389.5 & 1053.0 & 0.12 \\
\hline (3) $25000-<50000$ & 17584.7 & 1403.6 & 0.16 \\
\hline (4) $50000-<100000$ & 31576.6 & 1710.6 & 0.20 \\
\hline (5) $100000-<500000$ & 59268.1 & 2277.7 & 0.30 \\
\hline (6) $>=500000$ & 68947.7 & 2432.6 & 0.76 \\
\hline Total & 17159.8 & 1486.8 & 0.18 \\
\hline \multicolumn{3}{|c|}{ EU-28 } \\
\hline (1) $2000-<8000$ & 6234.4 & 1332.7 & 0.17 \\
\hline (2) $8000-<25000$ & 16299.0 & 1288.9 & 0.14 \\
\hline (3) $25000-<50000$ & 30292.4 & 1432.6 & 0.16 \\
\hline (4) $50000-<100000$ & 49274.7 & 1467.1 & 0.20 \\
\hline (5) $100000-<500000$ & 94643.0 & 2236.2 & 0.30 \\
\hline (6) $>=500000$ & 127902.3 & 3868.2 & 0.48 \\
\hline Total & 48375.3 & 2128.4 & 0.27 \\
\hline
\end{tabular}

Source: own elaboration based on EU FADN.

of a farm, the higher the increase in its competitive advantage determined by labour productivity. The difference between classes with the highest (6) and the lowest (1) value of this indicator was almost three-fold. Similar trends could be observed for farms in the EU. It is also noticeable that Polish farms in their respective classes of economic size were less competitive than their equivalents in the EU-28 (Table 4). On average, the value of output per 1 AWU was more than 31 thousand, almost three times higher in the EU-28 than in Poland. The economic size also determined the productivity of land which increased in higher classes of economic size. The value of output per 1 ha UAA across the entire population of farms was $1486.8 \mathrm{EUR} / \mathrm{ha}$ in the analysed period and, starting from class 4 upwards, it exceeded this level. For farms with the largest economic power it was $63.6 \%$ higher than average and almost three times higher than for the economically weakest farms. Likewise as regards labour productivity, Polish farms were not competitive in terms of land productivity in comparison to farms in the EU. The studies by Fan and Chan-Kang (2005, pp. 135-146) show that an increase in labour productivity is possible either through an increase in land productivity or an improvement in the relationship between land and labour. Another factor taken into account by the study is capital productivity. Farms in class 6 were the most competitive in that respect. Thus, it can be stated that economically strong farms reasonably adapted the level and structure of assets to the 
possibility of their efficient utilisation, and those with low economic power maintained their assets at an excessive level in relation to their production output. In the member states of the EU, likewise in Poland, an increase in capital productivity could be observed in higher classes of economic size. Studies by other authors (Bórawski, 2008, pp. 45-55; Orłowska, 2015, pp. 189-195) also suggest that variations in the productivity of the utilisation of the underlying production factors on farms are determined, among other things, by the economic size of the farm.

\section{Conclusion}

The studies focused on the competitive position of farms in Poland according to their economic size. The evaluation was based on selected profitability and productivity indicators. The studies revealed a relationship between the economic power of farms and the efficient utilisation of production factors. Economically stronger farms had a competitive advantage as regards the productivity of land, labour and capital, as well as work profitability. This must be connected with the fact that an increase in the productivity of agriculture is normally connected with the use of more effective techniques, more efficient inputs and biological progress. These, in turn, are usually used by farms of larger economic size. The conclusion is that continuing structural transformations in agriculture to optimise the structure of farms is justified. The studies revealed that labour input per 100 ha UAA was significantly higher in Poland than on average in the EU. In addition, along with the increase in the economic size of farms, the input decreased while the productivity of the factors went up. Thus competitive position is determined both by the economic size of farms and relationships between production factors. On the other hand, many factors affecting the competitiveness of farms are closely linked to them. Therefore, apart from endogenous conditions and results, further research should focus on exogenous conditions. Naturally, this makes the level and rate of changes in the competitiveness of farms extremely difficult to measure and describe. Hence continued studies with reference to uniform groups of farms, including groups identified according to economic size, are justified.

\section{References}

Bachev, H. (2017). Competitiveness of farming enterprises in Bulgaria. Annals of Agricultural \& Crop Sciences, 2(2), 1029.

Bórawski, P. (2008). Wielkość ekonomiczna jako czynnik różnicujący wyniki produkcyjne i ekonomiczne gospodarstw rolnych w regionie Pomorza i Mazur. Zeszyty Naukowe SGGWw Warszawie. Ekonomika i Organizacja Gospodarki Żywnościowej, (67), 45-55.

Chrobocińska, K. (2014). Uwarunkowania konkurencyjności gospodarstw użytkujących grunty z Zasobu Własności Rolnej Skarbu Państwa w województwie warmińsko-mazurskim. Roczniki Naukowe Ekonomii Rolnictwa i Rozwoju Obszarów Wiejskich, 101(1), 137-144. 
European Commission. (2009). European Competitiveness Report 2008. Communication from the Commission. COM(2008) 774 final. Brussels: European Commission.

FADN EU data base. Retrieved from https://ec.europa.eu/agriculture/rica/

Fan, S., and Chang-Kang, C. (2005). Is small beautiful? Farm size, productivity, and poverty in Asian agriculture. Agricultural Economics, 32(Supplement 1), 135-146.

Floriańczyk, Z., Osuch, D., and Płonka, R. (2018). Wyniki standardowe 2017 uzyskane przez gospodarstwa rolne uczestniczqce w polskim FADN. Część I. Wyniki standardowe. Warszawa: IERiGŻ-PIB.

Gałecka, A. (2017). Efektywność gospodarstw rolnych w Polsce w latach 2012-2015 w zależności od ich wielkości ekonomicznej. Roczniki Naukowe SERiA, 19(5), 65-71.

Gorynia, M. (2000). Koncepcja i metodyka badania konkurencyjności przedsiębiorstwa. In J. Bossak, W. Bieńkowski, J. Kruszewski (Eds.), Konkurencyjność gospodarki Polski w dobie integracji z Uniq Europejska i globalizacji, materiaty konferencyjne (89-102), Warszawa: Oficyna Wydawnicza SGH.

Grochowska, R., and Mańko, S. (2014). Produktywność gospodarstw rolnych w Polsce na tle innych krajów. Zeszyty Naukowe SGGW w Warszawie. Problemy Rolnictwa Światowego, 14(29), 1, 25-33.

Grzebyk, M., and Kryński, Z. (2011). Konkurencja i konkurencyjność przedsiębiorstw. Ujęcie teoretyczne. Nierówności społeczne a wzrost gospodarczy. Uwarunkowania sprawnego działania w przedsiębiorstwie i regionie. Zeszyty Naukowe Uniwersytetu Rzeszowskiego, (20), 107-117.

Główny Urząd Statystyczny [GUS]. (2017), Charakterystyka gospodarstw rolnych w $2016 \mathrm{r}$. Warszawa: Główny Urząd Statystyczny.

Kagan, A. (2015). Efektywność i konkurencyjność wielkotowarowych przedsiębiorstw rolnych. Warszawa: IERiGŻ-PIB.

Latruffe, L. (2010). Competitiveness, productivity and efficiency in the agricultural and agri-food sectors. (OECD Food, Agriculture and Fisheries Papers, No. 30). Rennes: OECD Publishing.

Marcysiak, A., and Marcysiak, A. (2015). Wpływ wielkości ekonomicznej gospodarstw na zakres wsparcia środkami wspólnej polityki rolnej Unii Europejskiej. Roczniki Naukowe SERiA, 17(4), 166-171.

Nasalski, Z. (2018). Endogeniczne czynniki konkurencyjności gospodarstw użytkujących grunty z Zasobu Własności Rolnej Skarbu Państwa w województwie warmińsko-mazurskim. Roczniki Naukowe SERiA, 20(4), 120-126.

Nosecka, B., Pawlak, K. and Poczta, W. (2011). Wybrane aspekty konkurencyjności rolnictwa. Warszawa: IERiGŻ-PIB.

Orłowska, M. (2015). Zasoby czynników produkcji oraz ich efektywność w gospodarstwach o różnej wielkości ekonomicznej w świetle FADN. Roczniki Naukowe SERiA, 17(2), 189-195.

Orłowska, M. (2019). Competitiveness of Polish organic farms with different economic size in light of FADN data. Annals of the Polish Association of Agricultural and Agribusiness Economists, 21(2), 217-224.

Poczta, W., and Siemiński, P. (2010). Konkurencyjność rolnictwa polskiego po przystapieniu do Unii Europejskiej. Poznań: Wydawnictwo Uniwersytetu Przyrodniczego w Poznaniu.

Sipa, M. (2007). Innowacje a konkurencyjność małych i średnich przedsiębiorstw w Polsce. Prace Naukowe Katedry Ekonomii i Zarzqdzania Przedsiębiorstwem, (6), 299-309.

Średzińska, J. (2017). Czynniki kształtujące dochody gospodarstw rolnych Unii Europejskiej według klas wielkości ekonomicznej. Prace Naukowe Uniwersytetu Ekonomicznego we Wrocławiu, (477), 305-314. 